\title{
Safety and effectiveness of different dosage of mifepristone for the treatment of uterine fibroids: a double-blind randomized clinical trial
}

This article was published in the following Dove Press journal:

International Journal of Women's Health

13 March 2013

Number of times this article has been viewed

\author{
Josep LL Carbonell' \\ Rita Acosta ${ }^{2}$ \\ Yasmiriam Pérez ${ }^{2}$ \\ Ana G Marrero \\ Edilia Trellez ${ }^{2}$ \\ Carlos Sánchez ${ }^{2}$ \\ Giuseppe Tomasi ${ }^{3}$ \\ 'Mediterránea Médica Clinic, \\ Valencia, Spain; ${ }^{2}$ Eusebio Hernández \\ Gynecology and Obstetrics Teaching \\ Hospital, Havana, Cuba; ${ }^{3}$ Basque \\ Country University, San Sebastian, \\ Spain
}

Objectives: The aim of this study was to evaluate the safety and improvement in quality of life using $10 \mathrm{mg}$ and $5 \mathrm{mg}$ daily doses of mifepristone for the treatment of uterine fibroids.

Design: The research was a randomized double-blind clinical study undertaken at the Eusebio Hernández Hospital in Havana, Cuba.

Subjects and methods: Seventy subjects with symptomatic uterine fibroids took one daily capsule of $10 \mathrm{mg}$ or $5 \mathrm{mg}$ mifepristone orally for 9 months. One to three endometrial biopsies were performed. In evaluating safety, the variables studied were endometrial changes associated with mifepristone, elevation of hepatic transaminases, side effects of mifepristone, and instances and duration of irregular bleeding.

Results: There were 30/49 (61.2\%) and 13/24 (54.2\%) diagnoses of endometrial changes associated with mifepristone in the $10 \mathrm{mg}$ and $5 \mathrm{mg}$ groups, respectively $(P=0.282)$. At every evaluation visit the average endometrial thickness was significantly greater in the $10 \mathrm{mg}$ group than in the $5 \mathrm{mg}$ group ( $P=0.013, P=0.002$, and $P=0.013$, respectively). Only five subjects had slight elevations in their hepatic transaminases after 9 months' treatment. Sixteen of 35 (45.7\%) and eight of 33 (24.2\%) subjects had the occasional hot flush in the $10 \mathrm{mg}$ and $5 \mathrm{mg}$ groups, respectively $(P=0.032)$. In total, there were $12.9 \pm 4.6(n=21)$ and $9.1 \pm 3.9(n=18)$ days of irregular bleeding in the $10 \mathrm{mg}$ and $5 \mathrm{mg}$ groups, respectively $(P=0.009)$.

Conclusion: According to the study findings, a $5 \mathrm{mg}$ daily dose over 9 months has a relatively better safety profile than the $10 \mathrm{mg}$ dose.

Keywords: mifepristone, leiomyoma, fibroid, antiprogestins

\section{Introduction}

The effectiveness of mifepristone in the treatment of uterine fibroids has been studied and demonstrated with $5 \mathrm{mg}$ and $10 \mathrm{mg}$ doses over 3-, 6-, and 12-month treatment periods in several trials. ${ }^{1-8}$ However, the quality of life afforded by this new therapeutic option has only been studied by Fiscella et al using doses of $5 \mathrm{mg}$ over 6-month treatment periods. ${ }^{9}$

Various other doses of this selective progesterone-receptor modulator (PRM) have also been evaluated, such as $50 \mathrm{mg}, 20 \mathrm{mg}$, and $12.5 \mathrm{mg}$, with or without pre-surgical indication. ${ }^{10-12}$ Recently, the European Medicines Agency authorized another medicine from this same chemical group to be commercialized - ulipristal - to be used for 3 months before surgery at a dose of $5 \mathrm{mg}$ daily.

The three main disadvantages of mifepristone $5 \mathrm{mg}$ and $10 \mathrm{mg}$ in treating uterine fibroids are raised - by $3 \%$ to $9 \%$ - subclinical hepatic transaminases (below $100 \mathrm{UI}$ aspartate transaminase [ASAT] and alanine transaminase [ALAT]) levels, ${ }^{1-7}$ minor
Correspondence: Josep Lluis Carbonell Mediterrania Medica Clinic, C/I4 Salvador Guinot, Valencia 46017, Spain Tel +34963586020 Fax +34963785485

Email josepcarbon@yahoo.es schja@infomed.sld.cu 
hot flushing in 10\%-20\% of cases, and intrauterine endometrial thickening of up to $15-25 \mathrm{~mm}$ caused by the climate of estrogenic prevalence resulting from the blocking of the progestin action - it can be of concern and occasionally leads to slight irregular bleeding. ${ }^{1-6}$

Various expert panels have shown that the histological modifications produced by the continuous administration of low-dose mifepristone are not simple hyperplasias, as was formerly understood, but constitute what are presently known as "progesterone-associated endometrial changes" (PAECs). PAECs characteristically present a series of histological features, including cyst-like dilations in the endometrial glands with occasional interior secretion, abnormal vessels, and changes in the glandular-connective tissue relationship. ${ }^{13,14}$

This research project aimed to study the safety of mifepristone treatment using $5 \mathrm{mg}$ and $10 \mathrm{mg}$ doses over a 9-month period and concentrating on its side effects, particularly with regard to endometrial thickening. A secondary objective was to evaluate quality of life via the Uterine Fibroid Symptom and Quality of Life (UFS-QOL) questionnaire. ${ }^{15}$

\section{Subjects and methods Design}

This was a double-blind randomized clinical trial, with two treatment groups, to evaluate safety and improvement in quality of life using $10 \mathrm{mg}$ and $5 \mathrm{mg}$ doses of mifepristone daily over 9 months for the treatment of uterine fibroids. A placebo group was not considered so as not to deprive the subjects of any therapeutic opportunity, since there is evidence that low-dose mifepristone reduces fibroid size, produces relief of associated symptomatology, and improves the subject's general condition. ${ }^{9,16}$

\section{Subjects}

Subjects were recruited from gynecological hospital classification consultancies and primary health care units. All subjects gave their informed consent to participate in the study. The study began in May 2009 and the last subject involved finished the 18-month follow-up period in December 2011.

Women, 18 years old or older, with uterine fibroids were eligible for the study. Inclusion criteria were: symptomatic uterine fibroids, fertile age, use of a non-hormonal contraceptive method, willingness to keep a monthly record of all vaginal bleeding episodes during treatment and of mifepristone side effects, willingness to undergo ultrasound examination at each evaluation and monitoring check-up, and agreement to at least two endometrial biopsies being performed. Women who were pregnant or wished to become pregnant, breastfeeding, using hormonal contraception or who had received hormonal therapy in the last 3 months, had signs or symptoms of pelvic inflammation, adnexal masses, abnormal or unexplained uterine bleeding, suspicion or diagnosis of malignant neoplasm, signs or symptoms of mental illness, adrenal disease, sicklecell disease, hepatic disease renal disease, bleeding disorders, had any other serious illness, and/or anti-progesterone contraindications were excluded from participating. Once the inclusion and exclusion criteria had been evaluated and all information needed for participating in the study was obtained, subjects gave their informed consent.

\section{Number of subjects}

Endometrial thickness was the variable used to calculate the size of the study sample. Based on the results of a previous study, ${ }^{5}$ in which $10 \mathrm{mg}$ mifepristone was used to treat uterine fibroids, it was assumed that after 9 months' treatment, the average endometrial thickness would be $14.0 \pm 3.5 \mathrm{~mm}$ and $11.0 \pm 3.5 \mathrm{~mm}$ in the $10 \mathrm{mg}$ and $5 \mathrm{mg}$ mifepristone groups, respectively. With 30 subjects in each treatment group, 60 subjects total, it would be possible to detect that difference with a Type I margin of error of 5\% and power of $90 \% .{ }^{17}$ The study sample was increased by approximately $15 \%$ to 35 subjects in each group (70 study subjects in total) to offset potential dropouts during the mifepristone treatment course.

\section{Assignation to treatment groups}

Subjects were randomly assigned to one of the two treatment groups according to the order of the assignation list drawn up by a computer. This was carried out as follows: staff not directly involved in the study prepared sealed opaque envelopes, numbered in consecutive order; each envelope contained a card indicating the treatment assigned to the subject. Once the subject had been evaluated in line with the inclusion and exclusion criteria and had signed informed consent, the envelope corresponding to the subject's numbered incorporation into the study was opened and she was included in the treatment group indicated on the card contained in the envelope - "mifepristone A" or "mifepristone B," where A corresponded to one of the mifepristone doses used in the study and B to the other. As the study was double blind, neither the doctor nor the subject knew which mifepristone group she had been assigned to.

\section{Treatment}

One group was treated with one $10 \mathrm{mg}$ capsule of mifepristone per day taken orally over 9 months (the $10 \mathrm{mg}$ group) and the other with one $5 \mathrm{mg}$ capsule of mifepristone per day taken orally 
over 9 months (the $5 \mathrm{mg}$ group). The mifepristone was supplied by Zizhu Pharmaceutical Laboratory, Beijing, People's Republic of China. The $5 \mathrm{mg}$ and $10 \mathrm{mg}$ capsules of mifepristone were prepared by L Amigó Pharmacy, Valencia, Spain. The $5 \mathrm{mg}$ and $10 \mathrm{mg}$ capsules of mifepristone were identical in appearance, size, shape, and color and could only be distinguished by a code that was destroyed once the study was over.

\section{Examinations performed}

Complete gynecological examination and abdominal or vaginal ultrasound examination of the uterus was undertaken in each subject before start of treatment, then after 3, 6 and 9 months of treatment. The posttreatment follow-up did not form part of the clinical study protocol, so as not to excessively inconvenience the subjects by making them attend appointments at which they would not receive treatment and it was left up to them whether to attend control visits every 3 months once the mifepristone treatment was over.

The subjects who attended follow-up visits 3, 6, 9, 12, 15, and 18 months after termination of treatment were also subject to a complete gynecological examination plus abdominal and vaginal ultrasound examination of the uterus. Uterine volume was calculated using the formula $0.524 \mathrm{~A} \times \mathrm{B} \times \mathrm{C}$, where $\mathrm{A}, \mathrm{B}$, and $\mathrm{C}$ are the diameters of the sphere in each of the three planes expressed in centimeters cubed. ${ }^{10}$ If the subject had more than one myoma, the largest was measured and its variations were used to evaluate effectiveness. The total uterine volume was calibrated using the previously described formula. Ultrasonography was used to calculate endometrial thickness in millimeters. All ultrasound data were obtained with an Aloka SSD-4000 ultrasound diagnostic machine (Tokyo, Japan) and two doctors specializing in ultrasound carried out the measurements. Calibrations taken at different stages of the study were performed with the sonographers blind to previous measurements and knowing only the localization of the myoma to be measured in case the subject had more than one such myoma.

Blood samples were taken for hematological tests and hepatic function at the first visit and after 3, 6, and 9 months' treatment; furthermore, hemoglobin $(\mathrm{Hb})$ was evaluated at the 3-, 6-, 9-, 12-, 15-, and 18-month follow-up visits. It was decided beforehand that, in line with US Food and Drug Administration recommendations, any subject presenting alterations in transaminases three or more times above their normal maximum limit would be dropped from the study. ${ }^{18}$

Endometrial biopsy was performed:

- prior to treatment if any of the following criteria applied: (a) there was endometrial thickness $>8 \mathrm{~mm}$, (b) there had been episodes of vaginal bleeding lasting more than 10 days, (c) there had been vaginal bleeding during the 3 weeks prior to onset of menstruation, and/or (d) there had been copious vaginal bleeding

- if any of the criteria described $a, b$, and $d$ were found during treatment

- on all subjects who, prior to the end of treatment, had not undergone a biopsy for any of a, b, c, or d.

Endometrial biopsy was performed under superficial general sedation with metal curettes. Endometrial samples were examined and analyzed independently by three hospital pathologists who had no previous knowledge of the initial biopsy results nor of the mifepristone dose the subject received. Histological evaluation of endometrial samples was done taking into account the findings of previous studies concerning changes in the endometrium brought about by mifepristone. ${ }^{13,14,18,19}$ Hyperplasia was defined according to World Health Organization criteria. ${ }^{20,21}$ Pathological endometrial biopsies were evaluated for the presence of endometrial intraepithelial neoplasia using criteria described by Mutter. $^{22}$

\section{Control visits and evaluation}

There were control or evaluation visits every 3 months through to the end of treatment. In each of these visits, the subject was given the mifepristone tablets that she needed until the following visit. Once treatment was over, the subjects were evaluated $3,6,9,12,15$, and 18 months later. During the follow-up period, no other treatment or placebo was administered that might shroud fibroid evolution or symptoms - thus, any chance of a placebo effect as a possible explication of an improvement sustained in the prevalence and intensity of symptoms was eliminated.

\section{Variables to evaluate efficacy}

Changes in endometrial thickness measured by ultrasound ( $\mathrm{mm}$ ) were evaluated at the beginning, at every visit during treatment, at the end, and every 3 months, up to a maximum of 18 months, following treatment. Mifepristone side effects - amenorrhea, hot flushes, nausea, sickness, vomiting, fatigue/tiredness - were also assessed. Any changes in hepatic transaminases prior to initiating treatment and over 3-month intervals until finalization of treatment were evaluated. Frequency of endometrial change associated with the administration of PRMs (ie, PAECs), and incidence of irregular bleeding during treatment were also recorded. These variables were measured at each visit during treatment and until its termination. 
It was agreed to define "amenorrhea" as the non-existence of bleeding greater than spotting; that is to say, subjects experiencing no heavier bleeding than spotting were considered to suffer from amenorrhea. "Irregular bleeding" was defined as bleeding including both spotting and more copious bleeding that did not surpass the subject's habitual menstrual intensity and duration.

\section{Variables to evaluate effectiveness}

The variables to evaluate efficacy were the percentage changes in fibroid and uterus volumes before treatment start, after 3, 6, and 9 months' treatment, and 3, 6, 9, 12, 15 and 18 months after termination of treatment. Other variables used to estimate efficacy were percentage changes in the prevalence of symptoms: pelvic pain, lumbar pain, rectal pain, pelvic pressure, urinary symptoms, dyspareunia, hypermenorrhea, and metrorrhagia. All these variables were measured in each of the study evaluation periods.

\section{Evaluation of quality of life}

Subjects completed the UFS-QOL questionnaire before and after treatment. The tool contains 37 items evaluating the subject's perception of uterine fibroid symptoms and changes in various areas of her life. ${ }^{15}$

\section{Presentation of results and statistics}

The results are presented in absolute frequencies, percentages, averages, standard deviations, and 95\% confidence intervals for the average values in endometrial thickness and fibroid and uterine volumes. Pearson's Chi-square test, the Student's $t$-test, and normal approximation for proportions were used to evaluate homogeneity and make comparisons between the two treatment groups. For comparisons within each treatment group with respect to the presence/absence of fibroid symptoms, McNemar's test was used.

The results of the questionnaire on quality of life are presented in tables that compare both treatment groups at the beginning and the end of treatment. These results were analyzed in line with the methodology referred to by Spies. ${ }^{15}$ In all cases, a $P$ value $<0.05$ was considered significant and all tests were two-tailed. Data were processed using SPSS software (v 11.5, IBM, Armonk, NY, USA).

\section{Results}

\section{Inclusion and adherence to treatment}

A total of 96 subjects were referred to the authors' consultative research center, 26 of whom did not meet the inclusion criteria, meaning that $70 / 96(73 \%)$ subjects were included in the clinical trial, 35 each in the $10 \mathrm{mg}$ and $5 \mathrm{mg}$ mifepristone groups. During treatment, four (11.4\%) subjects in the $5 \mathrm{mg}$ mifepristone group dropped out of the study: one dropped out after 1 month of treatment because she was concerned about the endometrial biopsy and one did not take the tablets after receiving them; the other two did not attend visits after the third month of treatment. There were no dropouts from the $10 \mathrm{mg}$ group during treatment. Data on subjects up to the moment they left the study are included in the results of the evaluation periods when they took mifepristone.

\section{Initial variables and comparison between treatment groups}

Table 1 shows the general characteristics of the subjects included in the study. There were no significant differences between the treatment groups in terms of characteristics. There was a significantly greater percentage of white subjects in the $10 \mathrm{mg}$ group $(P=0.007)$. In total, of the myomas studied, $14 / 70(20 \%)$ were subserous, 2/70 (2.9\%) were submucous, and 54/70 (77.1\%) were intramural. A significantly greater proportion of women had subserous fibroids in the $5 \mathrm{mg}$ group $(P=0.025)$ and intramural fibroids in the $10 \mathrm{mg}$ group $(P=0.026)$. In the $10 \mathrm{mg}$ mifepristone group, there was a significantly greater proportion of pelvic pressure symptoms, $P=0.039$. Fibroid-associated infertility was diagnosed in $3 / 35$ (7.7\%) and $4 / 35(12.9 \%)$ subjects in the $10 \mathrm{mg}$ and $5 \mathrm{mg}$ mifepristone groups, respectively. A single myoma was present in $12 / 35(34.3 \%)$ and $16 / 35(45.7 \%)$ subjects in the $10 \mathrm{mg}$ and $5 \mathrm{mg}$ mifepristone groups, respectively $(P=0.165)$, and there were no significant differences between the mifepristone groups $(P=0.136)$.

Table I Characteristics of subjects by treatment group

\begin{tabular}{lllll}
\hline Characteristics & Group & N & Average & SD \\
\hline Age, years & $10 \mathrm{mg}$ & 35 & 41.6 & 4.8 \\
Weight, $\mathrm{kg}$ & $5 \mathrm{mg}$ & 35 & 41.6 & 5.7 \\
& $10 \mathrm{mg}$ & 35 & 66.7 & 14.5 \\
Height, metres & $5 \mathrm{mg}$ & 35 & 70.9 & 15.1 \\
& $10 \mathrm{mg}$ & 35 & 1.6 & 0.1 \\
Body mass index & $5 \mathrm{mg}$ & 35 & 1.6 & 0.1 \\
& $10 \mathrm{mg}$ & 35 & 25.1 & 5.2 \\
Pregnancies & $5 \mathrm{mg}$ & 35 & 26.4 & 6.5 \\
& $10 \mathrm{mg}$ & 35 & 3.4 & 2.6 \\
Parturitions & $5 \mathrm{mg}$ & 35 & 3.2 & 1.9 \\
& $10 \mathrm{mg}$ & 35 & 1.0 & 0.9 \\
Induced abortions & $10 \mathrm{mg}$ & 35 & 1.9 & 1.1 \\
& $5 \mathrm{mg}$ & 35 & 1.4 & 1.9 \\
\hline
\end{tabular}

Abbreviation: SD, standard deviation. 


\section{Safety}

\section{Transaminases}

No subject in the $10 \mathrm{mg}$ and $5 \mathrm{mg}$ groups had raised ASAT or ALAT (reference values: 46 and 49 UI for ASAT and ALAT, respectively) at the 3- and 6-month control visits. In the 9-month visit, five subjects had raised transaminases, four in the $10 \mathrm{mg}$ group (two with raised ASAT alone, with scores of 50 and 52.4 UI, and two with raised ALAT alone, with scores of 57.6 and $62.8 \mathrm{UI}$ ) and one in the $5 \mathrm{mg}$ group, with 56 UI in ASAT level alone. No subject had both raised ASAT and ALAT levels at the same time.

\section{Hot flushes and amenorrhea}

Table 2 shows the frequency of subjects who reported having occasional hot flushes and who reported amenorrhea during mifepristone treatment. Over the 9 months of treatment, occasional hot flushes were reported by $16 / 35$ (45.7\%) and $8 / 33(24.2 \%)$ subjects in the $10 \mathrm{mg}$ and $5 \mathrm{mg}$ groups, respectively $(P=0.032)$.

\section{Nausea, vomiting, and fatigue}

At the 3-month visit, only 1/35 (2.9\%) subjects in the $10 \mathrm{mg}$ mifepristone group reported experiencing nausea; no subject in the $5 \mathrm{mg}$ group reported nausea during the same visit. At the 6-month visit, nausea was reported by $2 / 35$ (5.7\%) and $2 / 31(6.5 \%)$ subjects in the $10 \mathrm{mg}$ and $5 \mathrm{mg}$ groups, respectively. After 9 months' treatment, only one (2.9\%) subject in the $5 \mathrm{mg}$ group reported nausea and none in the $10 \mathrm{mg}$ group. No subject in either group reported vomiting at the 3-, 6-, or 9-month visits. One (2.9\%) subject in the $10 \mathrm{mg}$ group reported experiencing fatigue at the 3 month visit; no subjects in the $5 \mathrm{mg}$ group reported feeling fatigued during this visit. At the 6- and 9-month visits, no subject in either treatment group reported fatigue.

\section{Irregular bleeding}

At the 3 months visit 21/33 (61.7\%) of women in the $10 \mathrm{mg}$ group and 18/33 (51.4\%) of women in the $5 \mathrm{mg}$ group

Table 2 Hot flushes and amenorrhea at study evaluations

\begin{tabular}{lccc}
\hline Side effects, months & 10 $\mathbf{~ m g ~ g r o u p ~}$ & $\mathbf{5} \mathbf{~ m g}$ group & $\boldsymbol{P}$ \\
\hline Hot flushes & & & \\
3 & $8 / 35(22.9)$ & $4 / 33(12.1)$ & 0.123 \\
6 & $9 / 35(25.7)$ & $5 / 31(16.1)$ & 0.171 \\
9 & $8 / 35(22.9)$ & $4 / 31(12.9)$ & 0.148 \\
Amenorrhea & & & \\
3 & $34 / 35(97.1)$ & $33 / 33(100.0)$ & 0.164 \\
6 & $34 / 35(97.1)$ & $31 / 31(100.0)$ & 0.201 \\
9 & $28 / 35(80.0)$ & $31 / 31(100.0)$ & 0.004 \\
\hline Note: Values are presented as n(\%).
\end{tabular}

reported irregular bleeding $(P=0.235)$; the mean number of bleeding days was $6.1 \pm 4.8$ and $5.4 \pm 5.9(P=0.682)$, in the $10 \mathrm{mg}$ and $5 \mathrm{mg}$ mifepristone groups, respectively. At the 6-month visit, 19/35 (54.3\%) subjects in the $10 \mathrm{mg}$ group and $15 / 31(48.8 \%)$ subjects in the $5 \mathrm{mg}$ group reported some bleeding $(P=0.316)$; the mean number of bleeding days were $7.1 \pm 4.6$ and $4.9 \pm 3.1$, respectively $(P=0.105)$. At the 9 -month visit, irregular bleeding was reported by $14 / 35$ (40.0\%) of women in the $10 \mathrm{mg}$ group and 9/31 (29.0\%) women in the $5 \mathrm{mg}$ group; the mean number of bleeding days was $7.0 \pm 4.5$ in the $10 \mathrm{mg}$ group and $4.6 \pm 2.6$ in the $5 \mathrm{mg}$ group $(P=0.156)$.

In total, during the 9-month treatment phase, occasional irregular bleeding was reported by $21 / 35(60.0 \%)$ and $18 / 33$ (54.5\%) subjects in the $10 \mathrm{mg}$ and $5 \mathrm{mg}$ mifepristone groups, respectively $(P=0.325)$. Again in total, there were $12.9 \pm 4.6$ and $9.1 \pm 3.9$ days of irregular bleeding in the $10 \mathrm{mg}$ and $5 \mathrm{mg}$ groups, respectively $(P=0.009)$.

\section{Histological changes (endometrial biopsy) and endometrial thickness}

Pre-treatment biopsies were performed on 38/70 (54.3\%) subjects: secretory endometrium was diagnosed in $24 / 38$ (63.2\%), proliferative endometrium in $11 / 38$ (28.9\%), and $3 / 38(7.9 \%)$ were unsuitable for diagnosis. Endometrial biopsy was performed after 3 months' treatment on 13/35 (37.1\%) subjects in the $10 \mathrm{mg}$ group and on $3 / 33(9.1 \%)$ in the $5 \mathrm{mg}$ group $(P=0.003)$. Benign changes (PAECs) associated with the use of PRMs were diagnosed in 7/13 (53.8\%) and $3 / 3(100.0 \%)$ subjects in the $10 \mathrm{mg}$ and $5 \mathrm{mg}$ groups, respectively $(P=0.068)$.

After 6 months' treatment, an endometrial biopsy was performed on 19/35 (54.3\%) and 8/31 (25.8\%) subjects in the $10 \mathrm{mg}$ and $5 \mathrm{mg}$ mifepristone groups, respectively $(P=0.009)$. Benign changes (PAECs) associated with the use of PRMs were diagnosed in 12/19 (63.2\%) and 5/8 $(62.5 \%)$ subjects in the $10 \mathrm{mg}$ and $5 \mathrm{mg}$ groups, respectively $(P=0.487)$. One of the PAECs diagnosed in this round of biopsies had already been thus diagnosed in the biopsy carried out after 3 months' treatment. The remaining diagnoses were secretory endometrium and one menstrual endometrium

Nine months into treatment, an endometrial biopsy was performed on 17/35 (48.6\%) and 13/31 (41.9\%) subjects in the $10 \mathrm{mg}$ and $5 \mathrm{mg}$ mifepristone groups, respectively $(P=0.294)$. PAECs were diagnosed in $11 / 17(64.7 \%)$ and $5 / 13(38.5 \%)$ women in the $10 \mathrm{mg}$ and $5 \mathrm{mg}$ groups, respectively $(P=0.077)$. Three samples were unsuitable 
for diagnosis and the remaining diagnoses were secretory endometrium. In all the endometrial biopsies performed after 9 months' treatment, there were $30 / 49$ (61.2\%) and 13/24 (54.2\%) diagnoses of PAECs in the $10 \mathrm{mg}$ and $5 \mathrm{mg}$ groups, respectively $(P=0.282)$. There was no diagnosis of simple hyperplasia in any case.

Table 3 shows the changes in endometrial thickness during treatment with mifepristone. In the 3-month control visit, $17 / 35(48.6 \%)$ and $7 / 33(21.2 \%)$ subjects presented with endometrial thickness $>8 \mathrm{~mm}$ in the $10 \mathrm{mg}$ and $5 \mathrm{mg}$ groups, respectively $(P=0.009)$. After 6 months' treatment, there were $22 / 35(62.9 \%)$ and $10 / 31(32.3 \%)$ subjects with endometrial thickness $>8 \mathrm{~mm}$ in the $10 \mathrm{mg}$ and $5 \mathrm{mg}$ groups, respectively $(P<0.001)$. At the end-of-treatment visit ( 9 months), there were 16/35 (45.7\%) and 7/31 (22.6\%) subjects with endometrial thickness $>8 \mathrm{~mm}$ in the $10 \mathrm{mg}$ and $5 \mathrm{mg}$ groups, respectively $(P=0.025)$.

\section{Association between endometrial thickness, mifepristone dose, and PAECs}

In total, in all cases of PAECs, the average endometrial thickness was $16.6 \pm 6.3$ and $11.4 \pm 3.7 \mathrm{~mm}$ in the $10 \mathrm{mg}$ and $5 \mathrm{mg}$ mifepristone groups, respectively $(P=0.008)$.

\section{Effectiveness}

Tables 4 and 5 show the changes in fibroid and uterine volumes, respectively, at the times of study evaluation. At the end of treatment ( 9 months), there was no reduction in fibroid volume with respect to initial scores in 3/35 (8.6\%) and $5 / 31(16.1 \%)$ subjects in the $10 \mathrm{mg}$ and $5 \mathrm{mg}$ groups, respectively $(P=0.174)$. There was no reduction in uterine volume with respect to initial scores in 11/35 (31.4\%) and $7 / 31(22.6 \%)$ subjects in the $10 \mathrm{mg}$ and $5 \mathrm{mg}$ groups, respectively $(P=0.210)$.

In the $10 \mathrm{mg}$ and $5 \mathrm{mg}$ groups prior to treatment, there were $11 / 35(31.4 \%)$ and 9/35 (25.7\%) subjects with
$\mathrm{Hb} \leq 10 \mathrm{~g} / \mathrm{L}$, respectively $(P=0.298)$. Nine months into treatment, no subject had $\mathrm{Hb} \leq 10 \mathrm{~g} / \mathrm{L}$, in either of the mifepristone groups.

Table 6 shows changes in fibroid symptom frequency in all study evaluations.

\section{Evaluation of quality of life}

Before the treatment started, the total UFS-QOL test score was $60.7 \pm 26.3$ and $62.5 \pm 21.3$ points for the $10 \mathrm{mg}$ and $5 \mathrm{mg}$ groups $(P=0.766)$, respectively. Comparing both mifepristone groups once the treatment was over, the total UFS-QOL test score was $74.1 \pm 25.9$ and $77.7 \pm 20.3$ points for the $10 \mathrm{mg}$ and $5 \mathrm{mg}$ groups, respectively $(P=0.559)$. In the $10 \mathrm{mg}$ group, women began with an average score of $60.7 \pm 26.3$ points; at the end of the treatment, their scores had significantly improved to $74.1 \pm 25.9$ points $(22.1 \%$ of increment, $P=0.032$ ). In the case of the $5 \mathrm{mg}$ group, women began with an average score of $62.5 \pm 21.3$ points; at the end of treatment, their scores had significantly improved to $77.7 \pm 20.3$ points, $(24.3 \%$ of increment, $P=0.009)$.

\section{Posttreatment follow-up}

Of the subjects who finished the 9 months' treatment, the 6-month posttreatment control appointment was attended by $29 / 35(82.9 \%)$ of the $10 \mathrm{mg}$ mifepristone group and 18/31 $(58.1 \%)$ of the $5 \mathrm{mg}$ group. At the time of this visit, the average fibroid volume was $55.7 \%$ and $13.9 \%$ of its pre-treatment size in the 10 and $5 \mathrm{mg}$ mifepristone groups, respectively; the difference between treatment groups was not significant $(P=0.721)$. The average uterine volume was $33.9 \%$ and $0.6 \%$ of its pre-treatment size in the $10 \mathrm{mg}$ and $5 \mathrm{mg}$ mifepristone groups, respectively, and the difference in volume between the two groups was not significant $(P=0.574)$. Hb was below $10 \mathrm{~g} / \mathrm{L}$ in $8 / 29(27.6 \%)$ and $4 / 18(23.5 \%)$ of subjects in the $10 \mathrm{mg}$ and $5 \mathrm{mg}$ groups, respectively $(P=0.341)$. Endometrial thicknesses were $7.5 \pm 2.3$ and $6.9 \pm 1.4 \mathrm{~mm}$

Table 3 Changes in endometrial thickness during mifepristone treatment

\begin{tabular}{|c|c|c|c|c|c|c|}
\hline Evaluation & Group & $\mathbf{N}$ & Average \pm SD & Cl $95 \%$ for the average & $\%$ change & $P *$ \\
\hline \multirow[t]{2}{*}{ Before treatment } & $10 \mathrm{mg}$ & 35 & $6.8 \pm 2.5$ & $5.9-7.7$ & - & 0.220 \\
\hline & $5 \mathrm{mg}$ & 35 & $6.2 \pm 1.7$ & $5.5-7.0$ & - & \\
\hline \multirow[t]{2}{*}{3 months' treatment } & $10 \mathrm{mg}$ & 35 & $9.2 \pm 4.5$ & $7.7-10.7$ & $35.3 \% \uparrow$ & 0.013 \\
\hline & $5 \mathrm{mg}$ & 33 & $7.0 \pm 2.7$ & $5.6-7.2$ & $12.9 \% \uparrow$ & \\
\hline \multirow[t]{2}{*}{6 months' treatment } & $10 \mathrm{mg}$ & 35 & $11.5 \pm 6.3$ & $9.0-12.5$ & $69.4 \% \uparrow$ & 0.002 \\
\hline & $5 \mathrm{mg}$ & 31 & $7.4 \pm 2.6$ & $6.5-8.1$ & $19.4 \% \uparrow$ & \\
\hline \multirow[t]{2}{*}{9 months' treatment } & $10 \mathrm{mg}$ & 35 & $10.8 \pm 6.6$ & $8.8-14.0$ & $58.8 \% \uparrow$ & 0.013 \\
\hline & $5 \mathrm{mg}$ & 31 & $7.6 \pm 3.2$ & $6.4-8.4$ & $22.6 \% \uparrow$ & \\
\hline
\end{tabular}

Note: *t-test.

Abbreviations: $\mathrm{Cl}$, confidence interval; SD, standard deviation. 
Table 4 Changes in fibroid dimensions at study evaluations

\begin{tabular}{|c|c|c|c|c|c|c|}
\hline Evaluation & Group & $\mathbf{N}$ & Average \pm SD & $\mathrm{Cl} 95 \%$ for the average & $\%$ change & $P * *$ \\
\hline \multirow[t]{2}{*}{ Before treatment } & $10 \mathrm{mg}$ & 35 & $263 \pm 47 \mid$ & $78-306$ & - & 0.073 \\
\hline & $5 \mathrm{mg}$ & 35 & $115 \pm 100$ & $42-249$ & - & \\
\hline \multirow[t]{2}{*}{9 months' treatment } & $10 \mathrm{mg}$ & $34^{*}$ & $90 \pm 77$ & $9-165$ & $65.8 \% \downarrow$ & 0.035 \\
\hline & $5 \mathrm{mg}$ & 31 & $55 \pm 4 I$ & $24-118$ & $52.2 \% \downarrow$ & \\
\hline \multirow[t]{2}{*}{ Follow-up at 9 months } & $10 \mathrm{mg}$ & 29 & $196 \pm 118$ & $132-2 \mid 7$ & $25.5 \% \downarrow$ & 0.066 \\
\hline & $5 \mathrm{mg}$ & 16 & $130 \pm 94$ & $84-277$ & $13.0 \% \uparrow$ & \\
\hline \multirow[t]{2}{*}{ Follow-up at 18 months } & $10 \mathrm{mg}$ & 12 & $255 \pm 156$ & $135-375$ & $3.0 \% \downarrow$ & 0.190 \\
\hline & $5 \mathrm{mg}$ & 9 & $169 \pm 86$ & $84-223$ & $46.9 \% \uparrow$ & \\
\hline
\end{tabular}

Notes: *One fibroid was not measurable; ${ }^{*}{ }^{*}$-test.

Abbreviations: $\mathrm{Cl}$, confidence interval; $\mathrm{SD}$, standard deviation.

in the $10 \mathrm{mg}$ and $5 \mathrm{mg}$ mifepristone groups, respectively $(P=0.250)$. In $4 / 29(13.8 \%)$ and $2 / 18(11.1 \%)$ subjects in the $10 \mathrm{mg}$ and $5 \mathrm{mg}$ mifepristone groups, respectively, there was pelvic pain and hypermenorrhea.

The 12-month posttreatment control appointment was attended by $16 / 35$ (45.7\%) subjects of the $10 \mathrm{mg}$ mifepristone group and by $9 / 31(29.0 \%)$ of the $5 \mathrm{mg}$ group. The average fibroid volume was $27.4 \%$ and $9.6 \%$ of its pre-treatment size in the $10 \mathrm{mg}$ and $5 \mathrm{mg}$ mifepristone groups, respectively; the difference between the treatment groups was not significant $(P=0.088)$. The average uterine volume was $10.4 \%$ and $23.8 \%$ of pre-treatment size in the 10 and $5 \mathrm{mg}$ mifepristone groups, $P=0.525$. Hemoglobin was below $10 \mathrm{~g} / \mathrm{L}$ in $2 / 16(12.5 \%)$ and $1 / 9(11.1 \%)$ subjects in the 10 and $5 \mathrm{mg}$ groups, $P=0.459$. Endometrial thicknesses were $7.7 \pm 1.7$ and $7.2 \pm 1.5 \mathrm{~mm}$ in the 10 and $5 \mathrm{mg}$ mifepristone groups, respectively, $P=0.514$.

In $3 / 16(18.8 \%)$ and $1 / 9(11.1 \%)$ subjects in the $10 \mathrm{mg}$ and $5 \mathrm{mg}$ mifepristone groups, respectively, there was pelvic pain and metrorrhagia. In 2/9 (22.2\%) subjects in the $5 \mathrm{mg}$ group there was hypermenorrhea.

The 18-month posttreatment control appointment was attended by $10 / 35$ (28.6\%) and $9 / 31$ (29.0\%) subjects of those who finished the 9 months' treatment in the $10 \mathrm{mg}$ and $5 \mathrm{mg}$ mifepristone groups, respectively. The average fibroid volume was $3.0 \%$ less than the initial value in the $10 \mathrm{mg}$ group and $46.9 \%$ greater than initially in the $5 \mathrm{mg}$ group; the difference was not significant $(P=0.190)$. The average uterine volume was $3.0 \%$ and $31.9 \%$ greater to initial values in the $10 \mathrm{mg}$ and $5 \mathrm{mg}$ mifepristone groups, respectively, with no significant difference between them $(P=0.400)$. No subjects had $\mathrm{Hb}<10 \mathrm{~g} / \mathrm{L}$. Average endometrial thicknesses were $6.9 \pm 0.7$ and $7.0 \pm 1.0 \mathrm{~mm}$ in the $10 \mathrm{mg}$ and $5 \mathrm{mg}$ mifepristone groups, respectively $(P=0.806)$.

\section{Discussion}

As far as the authors are aware, at time of writing this is the only study to have administered mifepristone for 9 months continuously. It should be pointed out that at the beginning of the study, the average uterine volume was significantly greater in the $10 \mathrm{mg}$ group $(P=0.006)$. The average fibroid volume in the $10 \mathrm{mg}$ group differed asymptotically from the $5 \mathrm{mg}$ group $(P=0.073)$. At the beginning, the main differences between the two treatment groups were that there was a greater proportion of white subjects in the $10 \mathrm{mg}$ group $(P=0.007)$, a greater proportion of subserous fibroids in the $5 \mathrm{mg}$ group $(P=0.025)$ and of intramural fibroids in the $10 \mathrm{mg}$ group $(P=0.026)$, and a greater proportion of pelvic pressure symptoms in the $10 \mathrm{mg}$ group $(P=0.039)$.

Table 5 Changes in uterine dimensions at study evaluations

\begin{tabular}{|c|c|c|c|c|c|c|}
\hline Evaluation & Group & $\mathbf{N}$ & Average \pm SD & $\mathrm{Cl} 95 \%$ for the average & $\%$ change & $P^{*}$ \\
\hline \multirow[t]{2}{*}{ Before treatment } & $10 \mathrm{mg}$ & 35 & $866 \pm 578$ & $499-1090$ & - & 0.006 \\
\hline & $5 \mathrm{mg}$ & 35 & $542 \pm 362$ & $396-1143$ & - & \\
\hline \multirow[t]{2}{*}{9 months' treatment } & $10 \mathrm{mg}$ & 35 & $533 \pm 570$ & $347-640$ & $38.5 \% \downarrow$ & 0.117 \\
\hline & $5 \mathrm{mg}$ & 31 & $361 \pm 175$ & $289-570$ & $33.4 \% \downarrow$ & \\
\hline \multirow[t]{2}{*}{ Follow-up at 9 months } & $10 \mathrm{mg}$ & 29 & $514 \pm 369$ & $328-779$ & $40.6 \% \downarrow$ & 0.873 \\
\hline & $5 \mathrm{mg}$ & 16 & $533 \pm 452$ & $237-805$ & $1.7 \% \downarrow$ & \\
\hline \multirow[t]{2}{*}{ Follow-up at 18 months } & $10 \mathrm{mg}$ & 12 & $892 \pm 412$ & $582-1203$ & $3.0 \% \uparrow$ & 0.400 \\
\hline & $5 \mathrm{mg}$ & 9 & $715 \pm 433$ & $373-1154$ & $31.9 \uparrow$ & \\
\hline
\end{tabular}

Note: $*_{\text {t-test. }}$

Abbreviations: $\mathrm{Cl}$, confidence interval; SD, standard deviation. 
Table 6 Prevalence (\%) of fibroid symptoms at study evaluation times by treatment group

\begin{tabular}{|c|c|c|c|}
\hline Fibroid symptoms & 10 mg group & $5 \mathrm{mg}$ group & $P$ \\
\hline \multicolumn{4}{|l|}{ Pelvic pain } \\
\hline Before treatment & 82.1 & 83.9 & 0.421 \\
\hline 9 months' treatment & 2.6 & II.I & 0.076 \\
\hline Follow-up at 9 months & 10.3 & 6.3 & 0.322 \\
\hline Follow-up at 18 months & 10.0 & II.I & 0.469 \\
\hline \multicolumn{4}{|l|}{ Pelvic pressure } \\
\hline Before treatment & 69.2 & 48.4 & 0.039 \\
\hline 9 months' treatment & 0.0 & 0.0 & - \\
\hline Follow-up at 9 months & 0.0 & 6.3 & 0.087 \\
\hline Follow-up at 18 months & 0.0 & II.I & 0.139 \\
\hline \multicolumn{4}{|l|}{ Urinary symptoms } \\
\hline Before treatment & 36.0 & 22.3 & 0.114 \\
\hline 9 months' treatment & 0.0 & 0.0 & - \\
\hline Follow-up at 9 months & 0.0 & 0.0 & - \\
\hline Follow-up at 18 months & 0.0 & II.I & 0.139 \\
\hline \multicolumn{4}{|l|}{ Lumbar pain } \\
\hline Before treatment & 41.0 & 32.3 & 0.225 \\
\hline 9 months' treatment & 5.1 & 0.0 & 0.116 \\
\hline Follow-up at 9 months & 0.0 & 0.0 & - \\
\hline Follow-up at 18 months & 0.0 & 0.0 & - \\
\hline \multicolumn{4}{|l|}{ Rectal pain } \\
\hline Before treatment & 20.5 & 16.1 & 0.320 \\
\hline 9 months' treatment & 0.0 & 0.0 & - \\
\hline Follow-up at 9 months & 0.0 & 0.0 & - \\
\hline Follow-up at 18 months & 0.0 & 0.0 & - \\
\hline \multicolumn{4}{|l|}{ Dyspareunia } \\
\hline Before treatment & 43.6 & 32.3 & 0.168 \\
\hline 9 months' treatment & 0.0 & 0.0 & - \\
\hline Follow-up at 9 months & 0.0 & 0.0 & - \\
\hline Follow-up at 18 months & 0.0 & 0.0 & - \\
\hline \multicolumn{4}{|l|}{ Hypermenorrhea } \\
\hline Before treatment & 87.9 & 87.1 & 0.465 \\
\hline 9 months' treatment & 0.0 & 0.0 & - \\
\hline Follow-up at 9 months & 6.9 & 6.3 & 0.467 \\
\hline Follow-up at 18 months & 10.0 & II.I & 0.469 \\
\hline \multicolumn{4}{|l|}{ Metrorrhagia } \\
\hline Before treatment & 20.5 & 25.8 & 0.300 \\
\hline 9 months' treatment & 0.0 & 0.0 & - \\
\hline Follow-up at 9 months & 0.0 & 0.0 & - \\
\hline Follow-up at 18 months & 0.0 & 0.0 & - \\
\hline
\end{tabular}

\section{Safety}

\section{Transaminases}

The number of cases, 5/66 (7.6\%), with elevated transaminases is comparable to the results published in other studies; ${ }^{1-7}$ however, these five cases occurred between 6 and 9 months of treatment - during the first 6 months, there was not a single case of elevated transaminases. Further, it should also be pointed out that the elevation was minimal, with the maximum score $56 \mathrm{UI}$ for ASAT and $62.8 \mathrm{UI}$ for ALAT. None of the five cases had simultaneous elevations of both transaminases; only one of the two was elevated at any one time, the other being inside normal values.

\section{Hot flushes}

In this study, hot flush frequency evaluated over the 3-month treatment periods was quite similar to that obtained in our previous studies in both treatment groups. ${ }^{1-6}$ When this parameter was evaluated globally over the 9 months, the percentage of subjects who experienced at least the occasional hot flush rose to $41 \%$ and $25.5 \%$ in the $10 \mathrm{mg}$ and $5 \mathrm{mg}$ groups, respectively. While it is a limitation of this study that neither the intensity nor the duration of the hot flushes was measured, it should be noted that this symptom did not result in any subjects dropping out or requesting such. This is compatible with the subjective opinion of medical researchers that the light hot flushes experienced as a side effect of mifepristone treatment are less intense than those experienced during the menopause or those brought on by other medicines such as gonadotropin-releasing hormone analogs; this is logical if one realizes that the serum rate of estradiol with $5 \mathrm{mg}$ of mifepristone is at the same level as in the early or mid-follicular phase, even when ovulation is inhibited by the mifepristone. ${ }^{23,24}$

\section{Amenorrhea}

After 9 months' treatment, the $5 \mathrm{mg}$ group had a higher percentage of amenorrhea than the $10 \mathrm{mg}$ group with $P=0.010$. However, we believe this may be a somewhat accidental finding, probably due to the combination of the smaller fibroid size, greater significant proportion of subserous fibroids $(P=0.025)$, which should not provoke bleeding, and the smaller increase in endometrial thickness in the $5 \mathrm{mg}$ group.

\section{Histological changes (endometrial biopsy) and endometrial thickness}

The PAEC percentages obtained in this study in the 6-month biopsies were superior in both groups to those obtained in our previous study after 6 months' treatment; ${ }^{5}$ however, unlike in that study, where there was a significant difference between the percentages obtained in the $10 \mathrm{mg}$ and $5 \mathrm{mg}$ groups, $44.3 \%$ and $27.9 \%$, respectively ( $P=0.03$ ), in the present study that difference was not present, as the PAEC percentages were equal in both groups. Increasing treatment by 3 months from 6 to 9 months did not seem to be accompanied by a significant increase in the number of PAECs in either of the two groups, with the greater proportion of PAECs in the $10 \mathrm{mg}$ group catching up with respect to the proportion in the $5 \mathrm{mg}$ group. However, Fiscella et al obtained similar proportions of PAECs with both 2.5 and $5 \mathrm{mg}$ doses. ${ }^{26}$ 
During the treatment period, a significant increase in endometrial thickness was clearly observed in the $10 \mathrm{mg}$ group (58.8\% versus $22.6 \%$ ) with a $P$ value 0.013 after 9 months' treatment. This difference disappeared when the subjects began to menstruate following termination of treatment, with endometrial thickness values falling to $<8 \mathrm{~mm}$ in both mifepristone groups. A significant direct relationship was observed between the higher endometrial thickness scores and diagnosis of PAECs $(P=0.001)$ in the $10 \mathrm{mg}$ group, unlike in the $5 \mathrm{mg}$ group, although an opposite tendency was observed that might become significant if the sample size had been greater. To sum up, in both groups there was an increase in endometrial thickness, which, in turn, may have caused irregular bleeding and a histological diagnosis of PAECs when a biopsy was performed; this was significantly more frequent in the $10 \mathrm{mg}$ mifepristone group.

\section{Quality of life}

Subjects' quality of life improved notably as a result of the treatment, with an increase of $22.1 \%$ and $24.3 \%$ in the $10 \mathrm{mg}$ and $5 \mathrm{mg}$ groups, respectively, in the total score obtained from the UFS-QOL questionnaire. ${ }^{15}$ There did not seem to be any statistically significant differences between the two mifepristone groups with respect to this quality of life evaluation. The improvement in quality of life observed in this study was similar to that obtained by other authors over shorter periods with doses of 2.5 and $5 \mathrm{mg}^{9}$ and was also similar to that obtained in observational studies of uterine artery embolization. ${ }^{25}$

\section{Effectiveness}

For up to 6 months' treatment, the results were practically identical to those obtained in our previous 6-month study. ${ }^{5}$ From 6 to 9 months, symptomatic improvement continued to hold up, although the percentage of amenorrhea in the $10 \mathrm{mg}$ group diminished noticeably to $82.1 \%$ versus $100.0 \%$ in the $5 \mathrm{mg}$ group $(P=0.010)$.

Uterine volume did not reduce further with 3 months' extra treatment, unlike fibroid volume which did, although not greatly. Thus, the authors do not therefore believe that there is much to be gained by extending treatment from 3-6 to 9 months.

\section{Follow-up}

As far as the authors are aware, this is the first study to have carried out follow-up for as long as 18 months. This very long follow-up period is probably the reason why participation was reduced so extensively at the end, thereby limiting the scientific value of any conclusions and tendencies that may have been observed had this not been the case. The fact that the follow-up was not an obligatory protocol may also have played an important role in the attrition rate. Thus, the data afforded in the follow-up period, especially in the final phase, does not allow us to draw any definitive conclusions due to the high percentage of follow-up dropouts, since this represents a significant bias and it is not clear why participants chose to continue or drop out.

\section{Conclusion}

In this study, the $5 \mathrm{mg}$ daily dose over 9 months was safer than the $10 \mathrm{mg}$ dose. Posttreatment follow-up periods lasting longer than 1 year are not recommended.

\section{Disclosure}

We would like to thank Laboratories Litaphar, S.A. for the free supplies of the mifepristone used in this clinical trial and also for their support. The authors declare no conflicts of interest in this work.

\section{References}

1. Carbonell Esteve JL, Acosta R, Heredia B, Pérez Y, Castañeda MC, Hernández AV. Mifepristone for the treatment of uterine leiomyomas: a randomized controlled trial. Obstet Gynecol. 2008;112(5): 1029-1036.

2. Carbonell Esteve JL, Quiróz Rámirez GM, Borge A, Castellón Zapata LE, Aragón WC, Tomasi G. Mifepristona $5 \mathrm{mg}$ frente a $10 \mathrm{mg}$ diarios en el tratamiento del leiomioma. Ensayo clínico aleatorizado [Mifepristone $5 \mathrm{mg}$ versus $10 \mathrm{mg}$ daily in the treatment of leiomyoma. Randomized Trial]. Progresos de Obstetricia y Ginecología. 2010;53(2):51-58. Spanish.

3. Carbonell JL, Acosta R, PérezY, Yero MC, Seigler I, Heredia B. Evolución del leiomioma uterino después del tratamiento con mifepristona. Ensayo clínico aleatorizado [Evolution of uterine leiomyoma after treatment with mifepristone: a randomized clinical trial]. Progresos de Obstetricia y Ginecología. 2010;53(6):231-236. Spanish.

4. Carbonell Esteve JL, Acosta R, Heredia B, et al. Mifepristona para tratamiento del fibroma uterino [Mifepristone to treat uterine fibroids] Revista Cubana de Obstetricia y Ginecología. 2010:36(2). Spanish.

5. Esteve JL, Acosta R, Pérez Y, Campos R, Hernández AV, Texidó CS Treatment of uterine myoma with 5 or $10 \mathrm{mg}$ mifepristone daily during 6 months, post-treatment evolution over 12 months: double-blind randomised clinical trial. Eur J Obstet Gynecol Reprod Biol. 2012;161(2): 202-208.

6. Carbonell Esteve JL, Riverón AM, Cano M, et al. Mifepristone $2.5 \mathrm{mg}$ versus $5 \mathrm{mg}$ daily in the treatment of leiomyoma before surgery. Int $J$ Womens Health. 2012;4:75-84.

7. Eisinger SH, Meldrum S, Ficella K, le Roux HD, Guzick DS. Low-dose mifepristone for uterine leiomyomata. Obstet Gynecol. 2003;101(2) 243-250.

8. Eisinger SH, Bonfiglio T, Fiscella K, Meldrum S, Guzick DS. Twelvemonth safety and efficacy of low-dose mifepristone for uterine myomas. J Minim Invasive Gynecol. 2005;12(3):227-233.

9. Fiscella K, Eisinger SH, Meldrum S, Feng C, Fisher SG, Guzick DS Effect of mifepristone for symptomatic leiomyomata on quality of life and uterine size: a randomized controlled trial. Obstet Gynecol. 2006; 108(6):1381-1387. 
10. Engman M, Granberg S, Williams AR, Meng CX, Lalitkumar PG, Gemzell-Danielsson K. Mifepristone for treatment of uterine leiomyoma. A prospective randomized placebo controlled trial. Hum Reprod. 2009;24(8):1870-1879.

11. Yang Y, Zheng S, Li K, et al. Treatment of uterine leiomyoma by two different doses of mifepristone. Zhonghua Fu Chan Ke Za Zhi. 1996; 31(10):624-626. Chinese.

12. Zeng C, Gu M, Huang H. A clinical control study on the treatment of uterine leiomyoma with gonadotrophin releasing hormone agonist or mifepristone. Zhonghua Fu Chan Ke Za Zhi. 1998;33(8):490-492.

13. Horn FM, Blithe DL. Progesterone receptor modulators and the endometrium: changes and consequences. Hum Reprod Update. 2007; 13(6):567-580.

14. Mutter GL, Bergeron C, Deligdisch, et al. The spectrum of endometrial pathology induced by progesterone receptor modulators. Mod Pathol. 2008;21(5):591-598.

15. Spies JB, Coyne K, Guaou Guaou N, Boyle D, Skyrnarz-Murphy K, Gonzalves SM. The UFS-QOL, a new disease-specific symptom and health-related quality of life questionnaire for leiomyomata. Obstet Gynecol. 2002;99(2):290-300.

16. Bagaria M, Suneja A, Vaid NB, Guleria K, Mishra K. Low-dose mifepristone in treatment of uterine leiomyoma: a randomised doubleblind placebo-controlled clinical trial. Aust N ZJ Obstet Gynecol. 2009; 49(1):77-83.

17. Faul F. G*Power [computer program]. Version 3.0.10. Kiel: Universitat Kiel. Germany.

18. US Department of Health and Human Services, Food and Drug Administration, US Department of Health and Human Services, Center for Biologics Evaluation and Research. Guidance for Industry: Drug-Induced Liver Injury; Premarketing Clinical Evaluation. Silver Spring and Rockville, MD: US Department of Health and Human Services, Food and Drug Administration, US Department of Health and Human Services, Center for Biologics Evaluation and Research; 2009. Available from: http://www.fda.gov/downloads/Drugs/.../Guidances/ UCM174090.pdf. Accessed November 12, 2012.
19. Spitz IM. Mifepristone: where do we come from and where are we going? Clinical development over a quarter of a century. Contraception. 2010;82(5):442-452.

20. Silverberg SG, Kurman RJ. Endometrial carcinoma. In: Atlas of Tumor Pathology: Tumors of the Uterine Corpus and Gestational Trophoblastic Disease. Washington DC: Armed Forces Institutes of Pathology; 1991:47-89.

21. Scully RE, Bonfiglio TA, Kurman RJ, Silverberg SG, Wilkinson EJ. Uterine corpus. In: Histological Typing of Female Genital Tract Tumors. 2nd ed. New York, NY: Springer-Verlag; 1994:13-31.

22. Mutter GL. EIN overview [web page on the Internet]. Harvard Medical School and Brigham Women's Hospital; nd. Available at: http://www.endometrium.org/EIN\%20Central/FramePages/ EINOverviewFrame\%28ModuleI\%29.htm. Accessed Jan 2008.

23. Baird DT, Brown A, Critchley HO, Williams AR, Lin S, Cheng L. Effect of long-term treatment with low-dose mifepristone on the endometrium. Hum Reprod. 2003;18(1):61-68.

24. Brown A, Cheng L, Lin S, Baird DT. Daily low-dose mifepristone has contraceptive potential by suppressing ovulation and menstruation: a double-blind randomized control trial of 2 and $5 \mathrm{mg}$ per day for 120 days. J Clin Endocrinol Metab. 2002;87(1):63-70.

25. Spies JB, Warren EH, Mathias SD, Walsh SM, Roth AR, Pentecost MJ. Uterine fibroid embolization: measurement of health-related quality of life before and after therapy. J Vasc Interv Radiol. 1999;10(10): 1293-1303.

26. Fiscella F, Bonfiglio T, Winters P, Eisinger SH, Fiscella K. Distinguishing features of endometrial pathology after exposure to the progesterone receptor modulator mifepristone. Hum Pathol. 2011;42(7):947-953.
International Journal of Women's Health

\section{Publish your work in this journal}

The International Journal of Women's Health is an international, peerreviewed open-access journal publishing original research, reports, editorials, reviews and commentaries on all aspects of women's healthcare including gynecology, obstetrics, and breast cancer. The manuscript management system is completely online and includes

\section{Dovepress}

a very quick and fair peer-review system, which is all easy to use. Visit http://www.dovepress.com/testimonials.php to read real quotes from published authors. 